\title{
Effect of Prepackaged Polymer on Compressive, Tensile and Flexural Strength of Mortar
}

\author{
Noor Ahmed Memon \\ Department of Civil Engineering \\ Quaid-e-Awam University of Engineering, \\ Science \& Technology \\ Nawabshah, Pakistan \\ nahmedmemon@gmail.com
}

\author{
Nawab Ali Lakho \\ Department of Civil Engineering \\ Quaid-e-Awam University of Engineering, \\ Science \& Technology \\ Nawabshah, Pakistan \\ nawablakho@gmail.com
}

\author{
Aijaz Hussain Larik \\ Department of Civil Engineering \\ Swedish College of Engineering and \\ Technology \\ Rahim Yar Khan, Pakistan \\ engraijazlarik@gmail.com \\ Muneeb Ayoub Memon \\ Department of Civil Engineering \\ Quaid-e-Awam University of \\ Engineering, Science \& Technology \\ Nawabshah, Pakistan \\ engr.muneebmemon@gmail.com
}

\author{
Muhammad Aslam Bhutto \\ Department of Civil Engineering \\ NED University of Engineering \& \\ Technology \\ Karachi, Pakistan \\ mabhutto@neduet.edu.pk
}

\author{
Ammaar Noor Memon \\ Department of Civil Engineering \\ Quaid-e-Awam University of \\ Engineering, Science \& Technology \\ Nawabshah, Pakistan \\ anmemon96@gmail.com
}

\begin{abstract}
Synthetic materials, like various types of polymers, are introduced as having cementitious qualities, which improve the system of pores of mortars and concretes by the formations of polymer films and thereby enhancing their strength and durability. This experimental study focuses to use a water-based pre-packaged grout powder containing polymer as cementitious material available in the local market under the brand ' $\mathrm{Hi}$ - bond (universal)' in mortar. The Hi-bond is added in mortar as partial replacement of cement. The replacement levels were from $2.5 \%$ to $10 \%$ of cement by weight with an increment of $2.5 \%$. In addition, same proportions mortar without $\mathrm{Hi}$-bond, was also tested to compare the Hi-Bond effectiveness in mortar. Mortars of three proportions; $1: 2,1: 3$ and $1: 4$ were cast and tested. The water-binder ratio was fixed at 0.5 . The specimens were cured in three curing conditions i.e., water, room temperature and natural environment (outside the room, open to sky). All specimens were tested after 28 days of curing. The mortar performance with and without Hi-Bond was investigated in terms of compressive strength, tensile strength and flexural strength. Enhancements in almost all the strength properties of mortar with Hi-bond were observed. A pronounced effect of curing condition and the mortar proportion is observed on the strength properties of the prepackaged polymer.
\end{abstract}

Keywords-prepackaged polymer mortar;compressive strength; tensile strength; flexural strength

\section{INTRODUCTION}

Cement mortars are a main component of construction industry, used in many applications over a structure such as finish and repair, concrete cover to reinforce concrete structures from environmental effects, manufacturing of ferrocement elements, mortar joints in brick masonry structures and protection layers to porous construction materials like light weight concrete elements or brick masonry walls [1-4]. Various additives including synthetic (resins and other polymers) and non-synthetic materials (fly ash, slag, silica fume etc) owing cementitious properties are used not only to enhance the strength properties of concrete mortars and grouts but their durability characteristics also [5-8].

Water based polymers are used in different ways in concrete and plain mortar. The polymers when used with cement and aggregates, the produced composite is known as polymer modified concrete (PMC) and polymer modified mortar (PMM). PMM consists of cement sand mixture, organic film-forming polymer latex in emulsion (liquid) form, and other related ingredients in appropriate ratios [10-11]. The other way is to mix polymer with the aggregate only without cement. The product is known as the polymer concrete (PC) and polymer mortar (PM). However the addition of polymers modifies many properties of concrete/mortar e.g. enhances strength properties, produces adhesion, reduces permeability, improves resistance against chemical attacks, exhibits high durability and is environmental friendly [12-15]. The above mentioned remarkable improvements in the properties of concrete with polymers encourage their use in many structural and non-structural applications in construction engineering [1619]. A wide variety of polymers is reported being used to modify the concrete and mortar. These may be in the forms of liquid resins, water based/water soluble latexes, redispersible powders etc. $[20,21]$. Since the polymer modified concretes and mortars are produced by adding polymers at the working place during the mixing of the other common ingredients of the concrete/mortar along with other admixtures, thus, control of the proportion of all the ingredients and the polymer dosage becomes very difficult causing a lot of variations in the final product from batch to batch [22-24]. This led to the 
development of prepackaged polymers which are produced from dispersible polymer powders. Prepackaged product is often in the form of powder which may only be mixed with water at the work place, which makes work more efficient. This technique facilitates to achieve accuracy of the batching and mixing [25]. Nowadays prepackaged polymer powders are produced by various manufacturers. In Pakistan a prepackaged polymer with the brand name of Hi-bond is available in the market.

A substantial experimental work is reported by various researchers [26-30] regarding the efficient use of Hi-bond (universal) in repair and rehabilitation and other applications of Hi-bond in concrete and grout. Since the pre-packaged polymers may also be used as an additive in the cement mortars their dosage and mortar proportion (cement: sand) shall affect the overall performance of the mortars. Further, the exposing conditions (curing conditions) also influence the strength and durability characteristics of the mortar. Therefore, this paper reports the results of the experimental study conducted to investigate the fundamental strength properties of mortars of different proportions with different dosage of Hi-bond exposed to three different curing conditions i.e., water, room temperature and natural environment (ambient temperature open to sky). The strength properties studied are compressive strength, tensile strength and flexural strength.

\section{MATERIALS AND METHODOLOGY}

Ordinary Portland cement (OPC) and Hi-bond (Universal) were selected as binder for this study. Three mix proportions of cement: sand were taken, 1:2, 1:3 and 1:4. Hi-bond was added up to $10 \%$ following an increment of $2.5 \%$ (starting from $0 \%$ ) by weight of cement. All five batches were cast and tested for each studied parameter (Table I).

\section{RESULTS AND DISCUSSION}

\section{A. Compressive Strength}

Table II presents the details of the results of the average mortar compressive strength. It can be that the compressive strength increases with increase in Hi-bond dosage in every case of mortar proportion and every exposing condition. This increase ranges between $2.1 \%$ and $21.3 \%$ depending upon the mortar proportion, Hi-bond dosage and exposing condition. The compressive strength of the mortar decreases when the proportion of sand in the mortar increases. An average reduction of $6 \%$ in compressive strength is recorded in the case of mortar 1:3 compared to the values of the mortar $1: 2$. This reduction in compressive strength reaches an average of $21 \%$ when compressive strength values of 1:4 mortar are compared to the corresponding values of 1:2 mortar. However, it is worth noting that the decrease in the compressive strength due to mortar proportion is independent of Hi-bond dosage. It is worth noting that the curing condition significantly affects the mortar's compressive strength. The mortar cured in water exhibited maximum values followed by the mortar cured in room temperature and natural temperature. The water cured mortars showed about $21 \%$ average increase in the compressive strength which reduced to $16 \%$ and $12 \%$ when cured in room temperature and natural temperature respectively. This inferred that likewise normal mortars the mortars with pre-packaged polymers are also curing conscious. Figures 1-3 depict the sample graphical views of effect of hibond, mix proportion and curing condition on the compressive strength of mortar.

TABLE I. DETAILS OF THE BATCHES CAST AND TESTED

\begin{tabular}{|c|c|c|c|}
\hline S. No. & $\begin{array}{c}\text { Batch } \\
\text { designation }\end{array}$ & $\begin{array}{c}\text { Hi-bond } \\
\text { dosage } \\
\mathbf{( \% )}\end{array}$ & Batch description \\
\hline 01 & CM & 00 & Cement mortar without Hi-bond \\
\hline 02 & CHBM2.5 & 2.5 & Cement mortar with $2.5 \%$ Hi-bond \\
\hline 03 & CHBM5 & 5.0 & Cement mortar with $5 \%$ Hi-bond \\
\hline 04 & CHBM7.5 & 7.5 & Cement mortar with $7.5 \%$ Hi-bond \\
\hline 05 & CHBM10 & 10.0 & Cement mortar with $10 \%$ Hi-bond \\
\hline
\end{tabular}

TABLE II. DETAILS OF CAST AND TESTED BATCHES

\begin{tabular}{|c|c|c|c|c|c|c|}
\hline \multicolumn{2}{|c|}{ Batch designation } & CM & \multicolumn{5}{c|}{ CHBM } \\
\hline \multicolumn{2}{|c|}{ Hi-bond dosage (\%) } & 0.0 & 2.5 & 5.0 & 7.5 & 10.0 \\
\hline $\begin{array}{c}\text { Curing } \\
\text { condition }\end{array}$ & $\begin{array}{c}\text { Mortar } \\
\text { proportion }\end{array}$ & \multicolumn{4}{|c|}{ Average compressive strength (MPa) } \\
\hline \multirow{4}{*}{ Water } & $1: 2$ & 16.0 & 16.9 & 18.0 & 18.9 & 19.4 \\
\cline { 2 - 7 } & $1: 3$ & 15.2 & 15.7 & 17.3 & 17.6 & 18.2 \\
\cline { 2 - 7 } & $1: 4$ & 12.5 & 13.6 & 14.4 & 14.7 & 15.0 \\
\hline \multirow{3}{*}{$\begin{array}{c}\text { Room } \\
\text { temperature }\end{array}$} & $1: 2$ & 14.2 & 15.1 & 16.0 & 16.4 & 16.7 \\
\cline { 2 - 7 } & $1: 3$ & 13.1 & 13.5 & 14.3 & 14.7 & 14.7 \\
\hline \multirow{2}{*}{$\begin{array}{c}\text { Natural } \\
\text { temperature }\end{array}$} & $1: 4$ & 9.7 & 10.3 & 10.9 & 11.2 & 11.2 \\
\cline { 2 - 7 } & $1: 2$ & 14.0 & 14.3 & 14.8 & 15.0 & 15.2 \\
\cline { 2 - 7 } & $1: 3$ & 12.0 & 12.5 & 13.0 & 13.3 & 13.5 \\
\hline
\end{tabular}

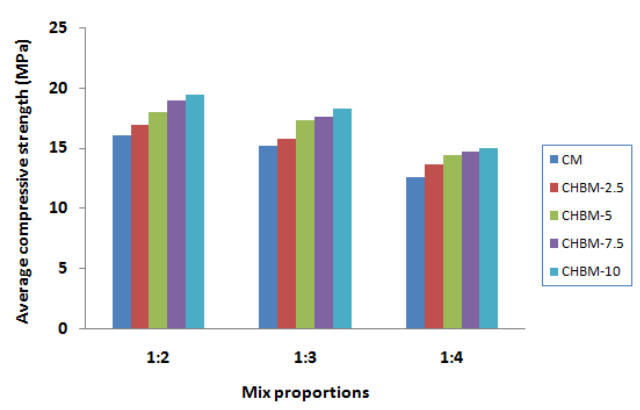

Fig. 1. Hi-bond effect on compressive strength of mortars cured in water

\section{B. Tensile Strength}

Tensile strength of mortar without and with different Hibond dosages exposed to the three curing conditions is presented in Table III. In terms of the effect of Hi-bond dosage and mix proportion, an identical trend to that of compressive strength is also observed in case of tensile strength. The tensile strength increases with the increase in Hi-bond dosage. The average increase in the tensile strength of mortar due to Hibond and cured in water is observed to be $28.7 \%$ followed by $19.9 \%$ and $19.6 \%$ when exposed to room temperature and natural temperature curing conditions respectively showing a little bit better mortar performance in terms of tensile strength. Tensile strength of mortar with 1:2 mix proportion was maximum followed by the tensile strength of 1:3 and 1:4 mix proportions. However, mortars exposed to room temperature showed anomaly by giving slightly higher tensile strength 
results than the mortars of same batch cured in water and natural temperature/environment which is shown in Figure 4. This infers that Hi-bond mortars can be applied in room temperature and natural (higher) temperature with more confidence and less wet curing particularly as plasters etc.

\section{Flexural Strength}

The experimental results of flexural strength are presented in Table IV. From the Table values it can be observed that the effect of Hi-bond in mortar is more pronounced in flexure strength than that observed in compressive and tensile strength. The maximum average increase in flexural strength is of the order of $74.4 \%$ and is obtained in the case of $1: 2$ mortar cured in water whereas, the minimum average increase in flexural strength is $32.9 \%$ in the case of $1: 4$ mortar cured in water. Individually maximum flexural strength increase is $94.4 \%$ exhibited by 1:2 mortar with 10\% Hi-bond and cured in water while the minimum value is $12.8 \%$ in case of $1: 4$ mortar with $2.5 \%$ Hi-bond dosage, again cured in water. This high impact of Hi-bond on flexural strength may be attributed to the strong formation of the matrix between binder (cement and Hi-bond combined) and sand particles due to the presence of Hi-bond. This may be considered as a positive sign because the mortar is used mostly for plaster applications and the manufacture of ferrocement elements where the major parameters of consideration are the tensile and flexural strength along with the reduced shrinkage. It is expected that a stronger matrix is liable to exhibit low shrinkage value. It is important to mention here that likewise tensile strength in flexure, the mortar with Hi-bond, exposed to room temperature, exhibited greater flexural strength than the ones cured in water and exposed to natural temperature which is visible in Figure 5.

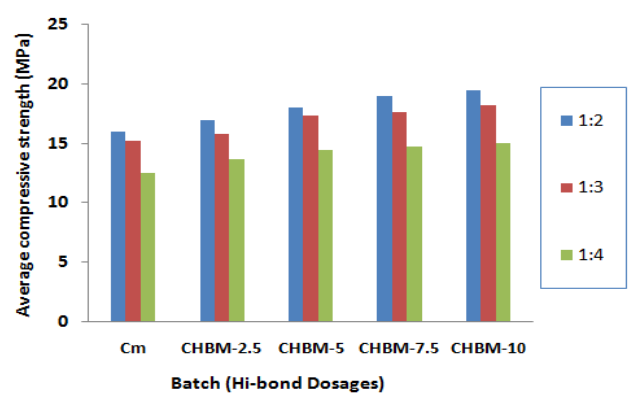

Fig. 2. Mix proportions effect on compressive strength of mortars cured in water

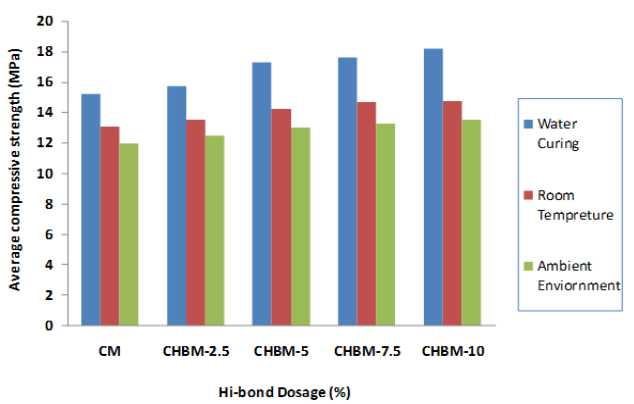

Fig. 3. Curing conditions effect on compressive strength of 1:3 mortars

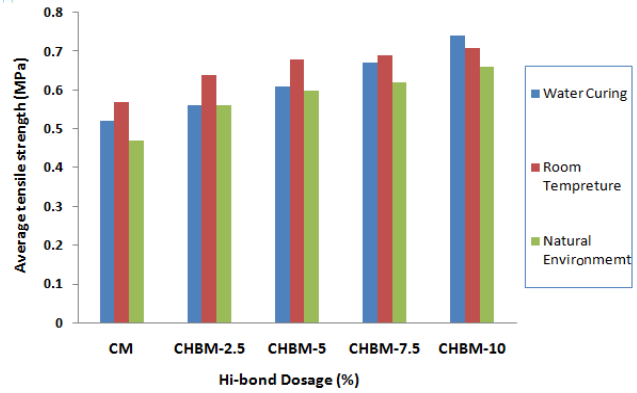

Fig. 4. Effect of curing conditions on tensile strength of 1:3 mortars

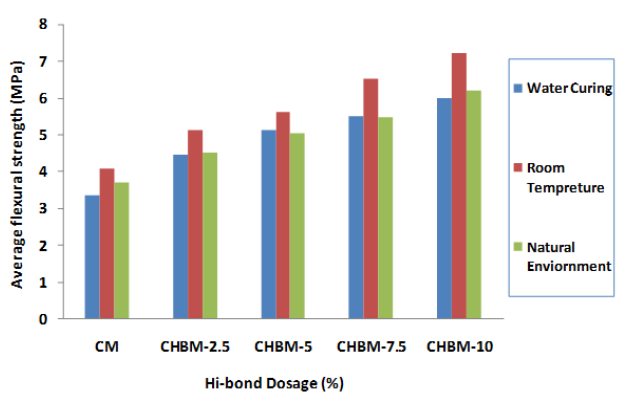

Fig. 5. Effect of curing conditions on flexural strength of 1:3 mortars

Fig. 6.

TABLE III. AVERAGE TENSILE STRENGTH OF MORTAR WITH PREPACKAGED POLYMER DETAILS

\begin{tabular}{|c|c|c|c|c|c|c|}
\hline \multicolumn{2}{|c|}{ Batch designation } & CM & \multicolumn{5}{|c|}{ CHBM } \\
\hline Hi-Bond dosage (\%) & 0.0 & 2.5 & 5.0 & 7.5 & 10.0 \\
\hline \multirow{2}{*}{$\begin{array}{c}\text { Curing } \\
\text { condition }\end{array}$} & $\begin{array}{c}\text { Mortar } \\
\text { proportion }\end{array}$ & \multicolumn{4}{|c|}{ Average tensile strength (MPa) } \\
\hline \multirow{3}{*}{ Water } & $1: 2$ & 0.61 & 0.69 & 0.73 & 0.80 & 0.89 \\
\cline { 2 - 7 } & $1: 3$ & 0.52 & 056 & 0.61 & 0.67 & 0.74 \\
\cline { 2 - 7 } & $1: 4$ & 0.44 & 0.47 & 0.54 & 0.64 & 0.72 \\
\hline \multirow{3}{*}{$\begin{array}{c}\text { Room } \\
\text { temperature }\end{array}$} & $1: 2$ & 0.66 & 0.69 & 0.77 & 0.81 & 0.84 \\
\cline { 2 - 7 } & $1: 3$ & 0.57 & 0.64 & 0.68 & 0.69 & 0.71 \\
\cline { 2 - 7 } & $1: 4$ & 0.45 & 0.49 & 0.52 & 0.57 & 0.61 \\
\hline \multirow{3}{*}{$\begin{array}{c}\text { Natural } \\
\text { temperature }\end{array}$} & $1: 2$ & 0.63 & 0.69 & 0.73 & 0.75 & 0.79 \\
\cline { 2 - 7 } & $1: 3$ & 0.47 & 0.56 & 0.60 & 0.62 & 0.66 \\
\cline { 2 - 7 } & $1: 4$ & 0.39 & 0.43 & 0.47 & 0.52 & 0.54 \\
\hline
\end{tabular}

TABLE IV. AVERAGE FLEXURAL STRENGTH OF MORTAR WITH PREPACKAGED POLYMER

\begin{tabular}{|c|c|c|c|c|c|c|}
\hline \multirow{2}{*}{ Batch designation } & CM & \multicolumn{5}{|c|}{ CHBM } \\
\hline \multicolumn{2}{|c|}{ Hi-Bond dosage (\%) } & 0.0 & 2.5 & 5.0 & 7.5 & 10.0 \\
\hline $\begin{array}{c}\text { Curing } \\
\text { condition }\end{array}$ & $\begin{array}{c}\text { Mortar } \\
\text { proportion }\end{array}$ & \multicolumn{4}{|c|}{ Average flexural strength (MPa) } \\
\hline \multirow{3}{*}{ Water } & $1: 2$ & 3.73 & 5.48 & 6.45 & 6.88 & 7.25 \\
\cline { 2 - 7 } & $1: 3$ & 3.36 & 4.46 & 5.13 & 5.50 & 5.99 \\
\cline { 2 - 7 } & $1: 4$ & 3.01 & 3.79 & 4.21 & 4.76 & 5.10 \\
\hline \multirow{3}{*}{$\begin{array}{c}\text { Room } \\
\text { temperature }\end{array}$} & $1: 2$ & 5.16 & 6.08 & 6.66 & 7.59 & 9.23 \\
\cline { 2 - 7 } & $1: 3$ & 4.09 & 5.14 & 5.61 & 6.51 & 7.23 \\
\cline { 2 - 7 } & $1: 4$ & 3.12 & 4.13 & 4.53 & 5.07 & 5.72 \\
\hline \multirow{2}{*}{$\begin{array}{c}\text { Natural } \\
\text { Temperature }\end{array}$} & $1: 2$ & 4.71 & 5.37 & 6.16 & 6.84 & 7.42 \\
\cline { 2 - 7 } & $1: 3$ & 3.71 & 4.52 & 5.03 & 5.49 & 6.20 \\
\cline { 2 - 7 } & $1: 4$ & 2.53 & 3.70 & 4.15 & 4.67 & 5.25 \\
\hline
\end{tabular}




\section{CONCLUSIONS}

Based on the experimental study's obtained results it may be concluded that the Hi-bond (a water based polymer) may be considered a promising material as cement replacement in the three tested mix proportions. It not only enhances the compressive strength but is more efficient in terms of tensile and flexural strength. Hi-bond mortars are found to be curing condition friendly. Hi-bond mortars may be considered less wet curing conscious, particularly in terms of tensile and flexural strength, with this aspect is suggested to be further studied in order to achieve a more concrete conclusion.

\section{ACKNOWLEDGMENT}

Authors are grateful to the Quaid-e-Awam University of Engineering, Science and Technology, Nawabshah for providing the research facilities.

\section{REFERENCES}

[1] A. A. Jatoi, Strength properties of cement mortar with silica fume, MSc Thesis, QUEST, Nawabshah, Sindh, Pakistan, 2014

[2] E. Sassoni, V. Sarti, A. Bellini, C. Mazzotti, E. Franzoni, "The role of mortar joints in FRP debonding from masonry", Composites Part B: Engineering, Vol. 135, pp. 166-174, 2018

[3] F. Ceroni, M. Leone, V. Rizzo, A. Bellini, C. Mazzotti, "Influence of mortar joints on the behaviour of FRP materials bonded to different masonry substrates", Engineering Structures, Vol. 153, pp. 550-568, 2017

[4] N. A. Memon, S. R, Sumadi, M. Ramli, "Ferrocement Encased Lightweight Aerated Concrete: A Novel Approach to Produce Sandwich Composite", Materials Letters, Vol. 61, No. 19-20, pp. 4035-4038, 2007

[5] A. Bourguiba, E. Ghorbel, L. Cristofol, W. Dhaoui, "Effects of recycled sand on the properties and durability of polymer and cement based mortars", Construction and Building Materials, Vol. 153, pp. 44-54, 2017

[6] N. A. Memon, S. R, Sumadi, M. Ramli, "Performance of high workability slag-cement mortar for ferrocement", Building and Environment, Vol. 42, No. 7, pp. 2710-2717, 2007

[7] L. Senff, R. C. E. Modolo, G. Ascensao, D. Hotza, V. M. Ferreira, J. A. Labrincha, "Development of mortars containing superabsorbent polymer", Construction and Building Materials, Vol. 95, pp. 575-584, 2015

[8] N. A. Memon, N. U. Keerio, M. A. Bhutto, S. R. Sumadi, "Experimental Study of Compressive Strength of Resin Grout with Marble Powder", European International Journal of Science Technology (IJEAT), Vol. 3, No. 4, pp. 87-95, 2014

[9] E. Knapen, D. Van Gemert, "Polymer film formation in cement mortars modified with water-soluble polymers", Cement and Concrete Composites, Vol. 58, pp. 23-28, 2015

[10] J. A. Thamboo, M. Dhanasekar, "Characterisation of thin layer polymer cement mortared concrete masonry bond Construction and Building Materials", Vol. 82, pp. 71-80, 2015

[11] M. U. K. Afridi, S. A. Rizwan, J. I. Memon, "A Revolutionary Prepackaged polymer modified super plasticizer mortar with field applications and Economic advantages", Pakistan Engineering Congress 68th Annual session proceedings, pp. 371-381, 2001

[12] ACI Committee 548, "Abstract of: State-of-the-Art Report on PolymerModified Concrete", Materials Journal, Vol. 91, No. 5, pp. 511-515, 1994

[13] Y. Ohama, "Principle of latex modification and some typical properties of latex modified mortar and concrete", Materials Journal, Vol. 84, No. 6, pp. 511-518, 1987
[14] J. Mirza, M. S. Mirza, R. Lapointe, "Laboratory and field performance of polymer-modified cement-based repair mortars in cold climates", Construction and Building Materials, Vol. 16, No. 6, pp. 365-374, 2002

[15] U. Müller, L. Miccoli, P. Fontana, "Development of a lime based grout for cracks repair in earthen constructions", Construction and Building Materials, Vol. 110, pp. 323-332, 2016

[16] M. Drdacky, F. Fratini, D. Frankeova, Z. Slizkova, "The Roman mortars used in the construction of the Ponte di Augusto (Narni, Italy)", Construction and Building Materials, Vol. 38, pp. 1117-1128, 2013

[17] K. A. Gour, R. Ramadoss, T. Selvaraj, "Revamping the traditional air lime mortar using the natural polymer -Areca nut for restoration application“, Construction and Building Materials, Vol. 164, pp. 255264,2018

[18] B. Isikdag, I. B. Topcu, "The effect of ground granulated blast-furnace slag on properties of Horasan mortar", Construction and Building Materials, Vol. 40, pp. 448-454, 2013

[19] M. Martínez-López, G. Martínez-Barrera, L. C. S. Nunes, J. M. L. Reis, H. S. da Costa Mattos, "Mixed mode fracture analysis in a polymer mortar using the Brazilian disk test", Engineering Fracture Mechanics, Vol. 154, pp. 140-151, 2016

[20] Y. Ohama, "Polymer-based admixtures", Cement and Concrete Composites, Vol. 20, No. 2-3, pp. 189-212, 1998

[21] S. I. Schneider, D. R. DeWacher, J. G. Palmer, "Redispersible polymer powders for tough, flexible cement mortars", In: Polymer-Modified Hydraulic-Cement Mixture, ASTM International, pp. 76-89, 1993

[22] A. Saand, Characteristics \& performance of concrete modified with prepackaged polymer-modified mortar, $\mathrm{PhD}$ Thesis, Universiti Teknologi Malaysia, 2008

[23] A. Saand, M. Ismail, S. R. Sumadi, "Influence of prepackaged polymerModified Mortar as a Modifier on strength of Concrete", Journal of Applied Sciences, Vol. 7, pp. 4023-4027, 2007

[24] S. Ahmad, A. Elahi, S. A. Barbhuiya, Y. Farid, "Use of Polymer modified mortar in controlling cracks in reinforced concrete beams", Construction and Building Materials, Vol. 27, No. 1, pp. 91-96, 2012

[25] M. U. K Afridi, Y. Ohama, S. Mubin, "Use of prepackaged polymermodified mortars as an effective earth quake resistant material", Science International (Lahore), Vol. 26, No. 3, pp. 1247-1251, 2014

[26] B. Craeye, M. Geirnaert, G. D. Schutter, "Super absorbing polymers as an internal curing agent for mitigation of early-age cracking of highperformance concrete bridge decks", Construction and Building Materials, Vol. 25, No. 1, pp.1-13, 2011

[27] ACI Committee E706, Field Guide to Concrete Repair Application Procedures: Structural crack repair by epoxy injection (ACI RAP Bulletin 1), ACI, 2003

[28] C. A. Issa, P. Debs, "Experimental study of epoxy repairing of cracks in concrete", Construction and Building Materials, Vol. 21, No. 1, pp. 15763, 2007

[29] E. David, C. Djelal, F. Buyle-Bodin, "Repair and strengthening of reinforced concrete beams using composite materials", In: 2nd international PhD Symposiumin civil engineering, Budapest, pp. 23-34, 1998

[30] D. Kachlakev, D. D. McCurry, "Behavior of full-scale reinforced concrete beams retrofitted for shear and flexural with FRP Laminates", Composites Part B: Engineering, Vol. 31, No. 6-7, pp.445-452, 2000 